\title{
The Australian Catholic University and DePaul University (Chicago) service-learning partnership
}

\author{
M. Pink, S. Jones \\ Australian Catholic University, Australia \\ H. Rosing \\ DePaul University, United States
}

\begin{abstract}
In this paper, we report on the service-learning partnership between Australian Catholic University and DePaul University (Chicago) and how this partnership has enriched the scholarship of service-learning for both institutions. Using a case study methodology, we explore how two large Catholic Higher Education Institutions (CHEIs) with similar, yet distinct missions have partnered to learn about each other's approaches and contexts. Since 2018, the SteansCenter for Community-Based Service-learning and Community Service Studies (DePaul) and ACU Engagement, the central agency responsible for supporting the extensive service-learning program at $A C U$, have met to discuss their programs and explore opportunities for collaboration. These discussions have led to new understandings and translations in the pedagogical terminology across Australian and US contexts and the identification of how mission coherence can inform partnerships between CHEIs. The partnership has also led to ongoing collaborations that have furthered the service-learning mission and institutionalisation of both universities. The paper concludes by reflecting upon the value of partnerships between CHEIs across national boundaries and the value of mutually exploring mission, principles, and practice as the field seeks further institutionalisation of service-learning. That is, service-learning for the mutual benefit and transformation of the community and university.
\end{abstract}

\section{Keywords}

Partnership, mission, knowledge exchange.

Fecha de recepción: 24/XI/2021

Fecha de aceptación: 9/XII/2021

\footnotetext{
Pink, M., Rosing, H. y Jones, S. (2021). The Australian Catholic University and DePaul (Chicago) servicelearning partnership. RIDAS, Revista Iberoamericana de Aprendizaje Servicio, 12, 136-148. DOI10.1344/RIDAS2021.12.14
} 


\section{El partenariado en aprendizaje-servicio de la Universidad Católica Australiana y la Universidad DePaul (Chicago)}

\section{Resumen}

Este artículo explica la relación de partenariado de aprendizaje-servicio entre la Universidad Católica de Australia y la Universidad DePaul (Chicago) y cómo esta asociación ha enriquecido el aprendizaje servicio para ambas instituciones. Mediante una metodología de estudio de caso, exploramos cómo dos grandes instituciones católicas de educación superior con misiones similares pero diferentes se han asociado para conocer sus enfoques y contextos. Desde 2018, ambas universidades se han reunido para discutir sus programas y explorar oportunidades de colaboración. Estas discusiones han dado lugar a nuevas interpretaciones y traducciones de la terminología pedagógica en contextos australianos y estadounidenses y a la identificación de cómo la coherencia de la misión puede informar a las asociaciones entre las instituciones católicas de educación superior. La asociación también ha dado lugar a colaboraciones continuas que han impulsado la misión del aprendizaje-servicio y su institucionalización en ambas universidades. El artículo concluye reflexionando sobre el valor de las asociaciones entre las instituciones católicas de educación superior a través de las fronteras nacionales y el valor de explorar mutuamente la misión, principios y práctica mientras se busca una mayor institucionalización del aprendizaje-servicio. Es decir, aprendizaje-servicio en beneficio mutuo y para la transformación de la comunidad y la universidad.

\section{Palabras clave}

Partenariado, misión, intercambio de conocimientos. 


\section{El partenariat en aprenentatge servei de la Universitat Catòlica Australiana i la Universitat DePaul (Chicago)}

\section{Resum}

Aquest article explica el partenariat en aprenentatge servei entre la Universitat Catòlica d'Austràlia i la Universitat DePaul (Chicago) i com aquesta associació ha enriquit l'aprenentatge servei per a ambdues institucions. Mitjançant una metodologia d'estudi de cas, explorem com dues grans institucions catòliques d'educació superior amb missions similars però diferents s'han associat per conèixer els seus enfocaments i contextos. Des del 2018, les dues universitats s'han reunit per discutir els seus programes i explorar oportunitats de col-laboració. Aquestes discussions han donat lloc a noves interpretacions i traduccions de la terminologia pedagògica en contextos australians i nord-americans i a la identificació de com la coherència de la missió pot informar les associacions entre les institucions catòliques d'educació superior. L'associació també ha donat Iloc a col-laboracions contínues que han impulsat la missió de l'aprenentatge servei i la seva institucionalització a les dues universitats. L'article conclou reflexionant sobre el valor de les associacions entre les institucions catòliques d'educació superior a través de les fronteres nacionals i el valor d'explorar mútuament la missió, els principis i la pràctica mentre es busca una major institucionalització de l'aprenentatge servei. És a dir, aprenentatge servei en benefici mutu i per a la transformació de la comunitat i la universitat.

\section{Paraules clau}

Partenariat, missió, intercanvi de coneixements. 


\section{Introduction}

Australian Catholic University (ACU), and DePaul University (Chicago) are the two largest English-speaking Catholic universities in the world. The universities have been associated with student exchange in multiple educational programs over the last 10 years. However, in the last 4 years there has been an intensified focus on partnering in the knowledge exchange on, and scholarship of, service-learning. In this paper, we report on how this partnership has enriched the scholarship of service-learning for both institutions.

\subsection{The institutions}

Australian Catholic University has eight Australian campuses as well as a campus in Rome and enrols over 34,000 students annually. ACU's core values are truth, academic excellence, and service, and the institution is guided by the following mission statement, "Within the Catholic intellectual tradition and acting in Truth and Love, ACU is committed to the pursuit of knowledge, the dignity of the human person and the common good" (Australian Catholic University [ACU], 2021, para. 1).

Service-learning is part of the Core Curriculum at ACU which all students complete regardless of professional program. This includes two coursework units that explore global issues of social justice with the principles of Catholic Social Thought (Byron, 1999) as a guiding framework. The Core also includes a discipline specific capstone service-learning unit where students gain experience working with communities who experience disadvantage and marginalisation. This translates to up to 4000 students completing service-learning each year. Service-learning at ACU is supported by ACU Engagement, a central agency whose role is to support faculty schools in their delivery of service-learning, raise the standard of service-learning, and to further institutionalise servicelearning and community engagement across ACU. As such, the function of ACU Engagement is to primarily facilitate, communicate, collaborate, and celebrate service-learning and community engagement.

DePaul is an urban university with two campuses in Chicago, Illinois. At the time of writing, the university enrols over 21,000 students across 10 colleges and schools. The university is deeply focused on its mission of serving the underserved inspired by the Vincentian charism. The DePaul mission calls for, Vincentian personalism that manifests as a belief in the God-given dignity of all people and a focus on care for the whole person (i.e., body, mind, and spirit), community, purpose, and social impact that affirms the worth of all people.

DePaul aims to achieve this through cultivating student and faculty values of inclusivity, personalism, and professionalism. The SteansCenter for Community-Based Service learning and Community Service Studies, its sister organization the Egan Office for Urban Education and Community Partnerships, both guided by the affiliated Asset- 
based Community Development Institute, support over 4000 students in service-learning courses, internships, and scholarships annually. Both institutions have developed clear principles of community engagement and service-learning and this can be seen in Table 1.

Table 1. ACU and DePaul Community Engagement and Service-learning principles

\section{Australian Catholic University Community} Engagement Principles

\begin{tabular}{ll}
\hline & ACU community engagement builds \\
genuine connections with community \\
organisations and the broader \\
community. It is through our being-in- \\
relationship that we are able to \\
develop empathic understanding, to \\
realise the fullness of our dignity, and \\
connections \\
to flourish as human beings. Through \\
the development of respectful \\
relationships and mutually beneficial \\
partnerships, university and \\
community can experience positive \\
individual and institutional growth.
\end{tabular}

ACU community engagement develops capacity and sustainability in the community through the virtue of humility. Humility allows us to look 'outward' with a sense of equality (not superiority or inferiority) and to work collaboratively with community instead of 'on' or 'for' community. Humility can help to minimise the power differentials inherent to some aspects of community work. Humility is a necessary precondition for genuine understanding and respect for human dignity. Humility opens our hearts to the contributions that those with whom we work bring to our relationships. Such a humble, non-judgmental, and non-moralistic approach honours the autonomy, and therefore the dignity, of all involved, so that together we form our consciences and work in ways that facilitate personal responsibility and, with it, human flourishing.

\section{RIDIS}

ACU community engagement aims to truly understand the people we work with. Empathic understanding involves listening and reflecting with one's heart and with one's intellect in order to come to a deep emotional and intellectual comprehension of the

Developing understanding beliefs, dispositions, needs, desires, and hopes of the people we work with, and of how these are shaped by experiences and environment. Based on such empathic understanding we can respond in a considered, compassionate, and respectful manner to develop meaningful outcomes with community, as community.

ACU community engagement recognises the inherent and equal moral worth and rights of all human beings, who are made in the image and likeness of God. Honouring the dignity of community members means working to ensure the protection and provision of fundamental human rights. It also means ensuring the development of people's capacities so

Affirming dignity that they can fully realise a sense of meaning, purpose and self-worth. Such a commitment to dignity translates into a fundamental orientation towards the support of those most marginalised and disadvantaged by the structures and attitudes of contemporary society. Supporting people's dignity means working with people in a holistic manner in a spirit of humility and collaboration for the common good.

ACU community engagement works for social justice. Through developing understanding, affirming human dignity, acting with humility, and building genuine connections, our community engagement works to stand in solidarity with those most in need, wherever they may be, and to advance the common good of our Pursuing societies. This means working for the Justice good of all, and for just and fair opportunities for participation in all aspects of society. The common good cannot be achieved if we ignore those most in need. Therefore, in ACU community engagement, there exists a fundamental orientation towards prioritising the needs of those who experience the most disadvantage and marginalization.

Pink, M., Rosing, H. y Jones, S. (2021). The Australian Catholic University and DePaul (Chicago) servicelearning partnership. RIDAS, Revista Iberoamericana de Aprendizaje Servicio, 12, 136-148. 


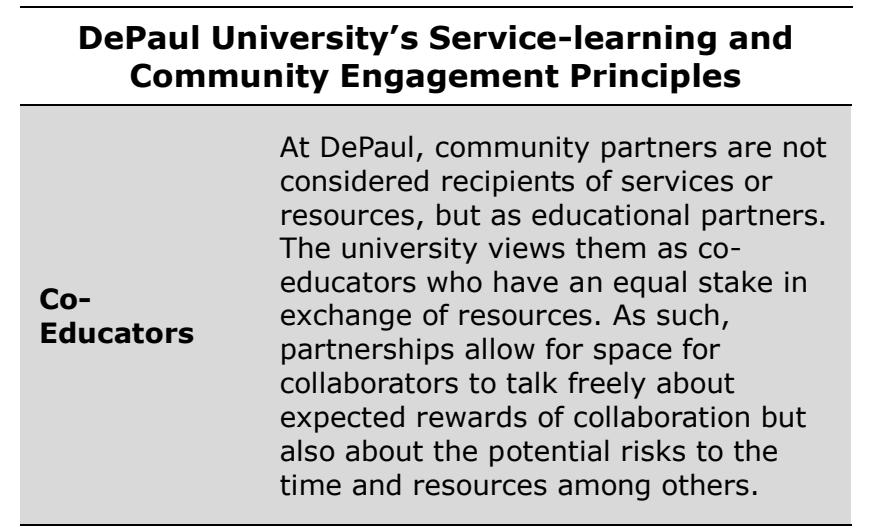

At DePaul, partnerships develop out of relationships resulting in mutual transformation and cooperation between parties. The university views

Mutual Transformation and Cooperation partnerships as motivated by a desire to combine forces to address the respective missions of DePaul and community partners. Ideally this results in outcomes greater than any one organization could achieve alone. Planned and transparent collaboration creates a sense of shared purpose with the goal of serving the common good.

DePaul employs a capacity building approach to community engagement by beginning with the premise that all communities have people with talents and skills; that all communities have assets. The university seeks to not only support communities in recognizing their assets but also to help mobilise community assets for development purposes. Rather that presume that outside sources can solve local problems, DePaul begins by working with existing community assets to build upon the work already going on in neighbourhoods.

DePaul ask that partners evaluate our community-university partnerships regularly. The university treats partners as community-based assets that require regular nurturing. DePaul asks partners to provide systematic critical self-reflection on the university's support in order to improve our efforts to build partners' capacities to serve members of the community.

\begin{tabular}{ll}
\hline & DePaul is committed to community \\
engagement that works for social \\
justice. The work is understood as \\
deeply political in the sense that there \\
is not one set of approaches to \\
resolving injustice or inequality. \\
Wocial & $\begin{array}{l}\text { Working for social justice begins with } \\
\text { austice }\end{array}$ \\
& subsequently building connections to \\
& resources that challenges systemic \\
& inequality.
\end{tabular}

Source: own elaboration

\subsection{The partnership}

Since 2018, the SteansCenter for Community-Based Service-learning and Community Service Studies (DePaul) and ACU Engagement have met to discuss their programs and explore opportunities for collaboration. These discussions have led to new understandings and translations in the pedagogical terminology across Australian and US contexts and the identification of how university mission coherence can inform a partnership between CHEIs. Further, the collaboration between the two universities has grown to incorporate meaningful knowledge production and exchange in the form of conferences (2019; 2021), scholarship (Joneset al., 2018; Pink et al., 2021), and new collaborations (e.g., student exchange) that seek to enhance the servicelearning efforts of both institutions in a spirit of reciprocity. In the following paper we report on a case study that explores the key outcomes of the burgeoning partnership and link this with the wider purpose of the Uniservitate program. 


\section{Methodology}

In this paper we utilised an exploratory case study (Yin, 2003) both to report upon the partnership historically and to identify key outcomes as pertinent to the field of service-learning generally, and partnerships between CHEIs specifically. Sources of data included historical documents pertaining to ACU and DePaul conferences, as well as previous publications and scholarship resulting from the partnership.

\section{Results and discussion}

\subsection{Engagement with, and scholarship} on critically engaged service-learning in Catholic institutions

Early in the partnership, and after a visit to DePaul from the Pro ViceChancellor, Engagement at ACU, effort went into exploring the similarities and differences between the two CHEIs. At first, working through appropriate translations in terminology took more time than expected. For example, the term 'Faculty' at ACU meant an entire department that housed multiple university schools (for example, the Faculty of Health Science) whereas at DePaul, Faculty refers to an individual academic staff member. Once semantic challenges were overcome, ACU benefited greatly from connecting with DePaul whose service-learning efforts were more advanced, yet, given the similar faith-based underpinnings of the institutions, ACU was able to borrow from DePaul's typology of servicelearning activities, and learn from their approaches with community.
Attention then shifted to producing scholarship that compared both institutions to enrich understanding of the service-learning approaches of two similar CHEIs. Jones et al. (2018) identified that both institutions saw service-learning as a pedagogy that goes beyond "one-off acts of charity or occasional volunteering" (Jones et al., 2018, p. 41). As such, mutuality, reciprocity, and capacity building are important to both institution's servicelearning efforts. Given the latter, both institutions favour activities that can lead to mutual transformation in the community and university at both individual and organisational/institutional levels. This type of service-learning goes beyond a transaction (Clayton et al., 2010), is time consuming, deep and committed, and in many instances in higher education is still aspirational (including at times in our own institutions). It became clear that the Catholic nature of ACU and DePaul, a central focus on affirming human dignity, working for the common good, developing a critical approach to service-learning and community engagement, and valuing subsidiarity (Brigham, 2012) meant that there was much desire for engagement that went beyond a rich learning opportunity for our students, and further still, beyond a mutually beneficial transaction. It would be remiss however not to recognise that this can be a challenge in a heavily commodified higher education environment (Marginson, 2013; McArthur, 2011). 


\subsection{Deepening our partnership}

It became apparent that there was merit in, and a desire to, connect service-learning practitioners from both institutions in a process of knowledge exchange and discussion. This generated an idea to host a partnered conference that aimed to more than just disseminate and discuss servicelearning, but also to identify further areas of learning and collaboration. A steering group with academic staff from both institutions worked on this concept for over a year and, with the support of an established communications and logistics team from ACU Engagement, hosted the inaugural ACU and DePaul Conference on Community Engagement and Service-learning (ACU, 2019). The conference occurred over three days during July 2019 at ACU's St Patrick's campus, Melbourne. One hundred and six academic and professional staff involved with community engagement and service learning attended the conference, which included 15 visiting faculty members from DePaul, and service-learning academics from New Zealand and the UK. Day one of the conference had a focus on 'celebrating university-community engagement and service-learning' with concurrent sessions organised into the fields of (a) health and science, (b) education, arts, and humanities, and (c) business, law, and social sciences. On the remaining days, the conference proceeded to 'funnel' and focus on furthering servicelearning and making concrete plans for collaborations at the ACU and DePaul level, but also between individual academics from both institutions. This occurred through roundtable discussions and breakout rooms. For example, a roundtable titled 'embedding community engagement/service-learning effectively in curriculum' highlighted the need to expand service-learning professional development for staff at ACU.

The inaugural conference provided a substantial opportunity to appreciate the similarities and differences between the two institutions. As discussed by Jaclyn Jensen, Associate Professor in the Department of Management and Entrepreneurship at DePaul who participated in the conference:
Participating in the conference was so rewarding to connect with colleagues who are working to inspire change in their communities, and connect classroom learning to real world application. It also reminded me of the global connections we share with colleagues who are leveraging our community-based assets to enhance student learning and engagement. We have much to learn from each other, and much to share. (DePaul University, 2020, para. 5)

One of the key learnings identified at the conference was that the commonality of the faith-based underpinnings of both institutions meant the need to prioritise work with communities who experience the most disadvantage and marginalisation. However, the Principles of Catholic Social Thought, the Vincentian Charism, and the general Catholic nature of ACU meant that this should be in a way that

Pink, M., Rosing, H. y Jones, S. (2021). The Australian Catholic University and DePaul (Chicago) servicelearning partnership. RIDAS, Revista Iberoamericana de Aprendizaje Servicio, 12, 136-148. DOI10.1344/RIDAS2021.12.14 
is assets-based, collaborates with community as equals, and affirms the dignity of all involved while building capacity. As such, the philosophical positions of both universities work well with the Carnegie Foundation's definition of university-community engagement (Saltmarsh \& Johnson, 2020). In addition, the knowledge production of the conference facilitated through thematic analysis by an independent provider also identified the following common learnings and challenges (Pink et al., 2021):

1. The value of embedding community engagement frameworks and approaches into curriculum;

2. The need for critical reflection on community engagement programs. Are they responsive to developing capacities?;

3. Enhancing the use of Assetsbased language and approaches in the CE/service-learning curriculum, and

4. The need to promote CE/ service-learning as a central pillar of our universities and an important manifestation of our teaching and research.

However, beyond this opportunity to connect and learn from each other's approaches, there were also some clear outcomes from the conference. This included partnering in reciprocal professional development (PD) seminars completed online, ongoing coauthoring of service-learning research papers, and a commitment to establishing a student service-learning exchange across institutions (with the latter stalled by the COVID-19 pandemic and associated travel restrictions). ACU and DePaul have now established a biennial tradition of partnered conferences with the most recent occurring in October, 2021. Over 200 delegates registered for the conference, which 'pivoted' to online and it was again an effective space for knowledge sharing and production. At the 2021 conference, delegates were encouraged to present with partners and students to allow these unique perspectives to be heard. In addition, the 2021 conference hosted the first ACU and DePaul student servicelearning discussion where 49 students representing both institutions met online to discuss their experiences in service-learning and identify common learnings and culturally specific differences. This event served as a precursor to physical exchanges. A substantial amount of work by an ACU and DePaul student service-learning exchange working group has also been happening in the background, with both institutions optimistic these exchanges will occur in the near future when international travel returns. Other collaborations resulting from the 2019 conference have included ACU and DePaul academic staff partnering in establishing virtual global learning exchanges in course subjects focussed on social justice.

The ACU and DePaul service-learning partnership continues to deepen, with the biennial conferences a wonderful 'springboard' to further collaborations. There has been great merit in 
connecting with another similar, yet distinct, CHEI to share the 'journey' of service-learning and commitment to raising standards as a manifestation of our university missions.

\section{Conclusions}

The partnership between ACU and DePaul continues to grow, and both institutions have been keen supporters and resources for the further development of each other's programs. DePaul had the opportunity to learn from ACU's approach to acknowledging and working with first peoples and have adjusted their formalities for important meetings. ACU in turn has benefited greatly with support and a sounding board for their work in supporting the Carnegie Foundation Community Engagement Classification pilot in Australia (University of Technology Sydney, 2020). DePaul received the Carnegie Classification in 2006 and 2015. For many years this classification system has encouraged increasingly higher standards of community engagement and servicelearning in the United States and is soon to become the standard in Australia (with contextual adjustments). The Carnegie system builds on the work of Andrew Furco (1999) and other service-learning pioneers to encourage increasing institutionalisation of service-learning. As such, the Carnegie system -as well as those CHEIs who have participated in classification- are an important resource for the Uniservitate program and other CHEIs seeking classification.

The ACU and DePaul partnership also provides an example of the many ways in which cross-institutional partnerships between CHEIs across national contexts can lead to further learning and development with respect to servicelearning. Examples such as these are important given the overarching objective of Uniservitate to:
Generate a systemic change in Catholic Higher Education Institutions (CHEIs) through the institutionalisation of service- learning as a tool to achieve its mission of offering an integral education to the new generations and involving them in an active commitment to the challenges of our time. (Uniservitate, 2020, para.2)

One of the key strengths of Uniservitate is that it encourages interaction and partnership across CHEIs; the ACU and DePaul partnership provides an early example of what can be achieved when two CHEIs connect in a spirit of ongoing collegiality and common interest for service-learning. In addition to encouraging partnership, Uniservitate offers the pedagogical support, funding and infrastructure to further this on a global scale and promote partnership and interaction that involves multiple universities.

Analysing the ACU and DePaul partnership has also helped to identify points of coherence between the Catholic mission and identities of our institutions and the purpose and desired outcomes of service-learning institutionalisation processes. Whether it is the Carnegie classification system (US/AUS/Canada), Towards a European Framework for Community Engagement

Pink, M., Rosing, H. y Jones, S. (2021). The Australian Catholic University and DePaul (Chicago) servicelearning partnership. RIDAS, Revista Iberoamericana de Aprendizaje Servicio, 12, 136-148. 
in Higher Education (O'Brien et al., 2021), or the Uniservitate program, community partners are viewed as more than just recipients of goods and services, or a learning experience for students, but rather as equal partners in a dynamic and mutually-beneficial exchange. All of these frameworks require that collaboration with community partners as equals in reciprocal ways that leads to transformation for both community and university (if it achieves optimal outcomes). As such, community partners should be co-collaborators in teaching, research, and service programs before, during, and after initiatives. Beyond best practice frameworks, such approaches are consistent with the Catholic nature and missions of ACU and DePaul meaning that principles of institutionalisation should be pursued as a matter of mission and identity. Specifically, if the service-learning of our institutions are to truly affirm the equal worth of the community partners we work with, then they should be treated as equal collaborators in the mutual exchange of knowledge, and there must be recognition that both sources of knowledge have equal value. Similarly, working under the auspices of subsidiarity means that community partners and members should have a substantial role in directing initiatives that relate to them.

Affirming dignity also relates to our own academics and staff members. Models of institutionalisation call for servicelearning teaching, research, and service to be recognised in reward systems and promotional criteria. When this occurs, service-learning is seen as an activity prioritised by the CHEI and this paves way for appropriate workload modelling, instead of service-learning being completed by a passionate few, often outside of working hours. Further still, in working for the common good we are called upon to evaluate and critically reflect on our works university wide to continually improve. The coherence between the principles of institutionalisation and our institutions' focus educating the whole person, working in engaged ways that affirm dignity, and pursues civic outcomes provides an opportunity to leverage institutionalisation processes while connecting to mission and identity.

The ACU and DePaul service-learning partnership provides an example of what can be achieved when CHEIs partner in knowledge exchange and production. The partnership is only in its infancy however the combination of similar philosophical underpinnings with enthusiasm for service-learning as a critical manifestation of mission and identity has meant that even in a short space of time there has been much development. This example of crossinstitutional, international collaboration provides support for the concept of the Uniservitate program and associated activities. As ACU and DePaul are both now involved with Uniservitate and CLAYSS, we look forward to deepening and widening our collaborations to further impact communities, student learning and faculty scholarship.

\section{Acknowledgements}

The authors would like to acknowledge all ACU and DePaul colleagues who

Pink, M., Rosing, H. y Jones, S. (2021). The Australian Catholic University and DePaul (Chicago) servicelearning partnership. RIDAS, Revista Iberoamericana de Aprendizaje Servicio, 12, 136-148. 
have contributed to and nourished the partnership and scholarship between our two institutions.

\section{References}

Australian Catholic University [ACU]. (2019). The ACU and DePaul Conference on Community Engagement and Service-learning.

https://www.acu.edu.au/aboutacu/communityengagement/conference-oncommunity-engagement-and-servicelearning/2019-celebrate-collaborateand-explore

Australian Catholic University [ACU]. (2021). Mission, Identity, and Values: Our Mission.

https://www.acu.edu.au/aboutacu/mission-identity-and-values/our$\underline{\text { mission }}$

Brigham, E. (2012). Creating a public space through service-learning. Teaching Theology \& Religion, 15(2), 145-155.

Byron, W. J. (1999). Framing the principles of Catholic social thought. Journal of Catholic Education, 3(1), 714.

Clayton, P., Bringle, R., Senor, B., Huq, J., \& Morrison, M. (2010).

Differentiating and assessing relationships in service-learning and civic engagement: Exploitative, transactional, or transformational. Michigan Journal of Community Service Learning, 16(2), 5-21.

DePaul University.(2021). University Mission Statement. https://offices.depaul.edu/missionministry/about/Pages/mission.aspx

DePaul University. (2020). Spotlight on a Global Partner - Australian Catholic University.

https://offices.depaul.edu/globalengagement/about/newsreports/Pages/spotlight-partnerfeature.aspx

Furco, A. (1999). Self-assessment rubric for the institutionalization of service-learning in higher education. https://digitalcommons.unomaha.edu/c gi/viewcontent.cgi?article $=1105 \&$ contex $\underline{\mathrm{t}=\mathrm{slces} \text { lgen }}$

Jones, S., Rosing, H., \& Pink, M. (2018). Community Engagement in Critically Engaged Catholic universities: Models from Australia and the US. Transform: The journal of engaged scholarship, 1(1), 39-53.

https://engagementaustralia.org.au/wp -content/uploads/2018/12/Article-

2 TRANSFORM-No-12018 Community-Engagement-inCritically-Engaged-Catholic-UniversitiesModels-from-Australia-and-the-US.pdf

Marginson, S. (2013). The impossibility of capitalist markets in higher education.Journal of Education Policy, 28(3), 353-370.

https://doi.org/10.1080/02680939.201 $\underline{2.747109}$

McArthur, J. (2011). Reconsidering the social and economic purposes of higher education. Higher Education Research \& Development, 30(6), 737-749.

https://doi.org/10.1080/07294360.201 $\underline{0.539596}$ 
O'Brien, E., Ilić, B., Veidemane, A., Dusi, D., Farnell, T., \& Schmidt, N. (2021). Towards a European framework for community engagement in higher education - a case study analysis of European universities. International Journal of Sustainability in Higher Education.

https://doi.org/10.1108/IJSHE-03$\underline{2021-0120}$

Pink, M. A., Rosing, H., Jones, S. C., \& Rose, F. (2021). The 2019 ACU and DePaul Conference on Community Engagement and Service-Learning: Learning, Challenges, and Opportunities. Manucsript in preparation.

Saltmarsh, J., \& Johnson, M. (2020). Campus classification, identity, and change: The elective Carnegie classification for community engagement. Journal of Higher Education Outreach and Engagement, 24(3), 105-114.

Uniservitate. (2020). What is

Uniservitate? .

https://www.uniservitate.org/project/

University of Technology

Sydney.(2020). Carnegie Community Engagement Classification Australian

Pilot.

https://www.carnegieclassificationaustr alia.com.au/

Yin, R. (2003).Case Study Research:

Design and Methods (Third ed.).

Thousand Oaks: Sage. 